\title{
The Legal Implications of Corporate Anti-corruption Culture
}

\author{
Nani Mulyati ${ }^{1}$, Aria Zurnetti ${ }^{2}$, Lucky Raspati ${ }^{3}$ \\ \{nanimulyati@1aw.unand.ac.id ${ }^{1}$, ariazurnetty@law.unand.ac.id ${ }^{2}$, luckyraspati@law.unand.ac.id ${ }^{3}$ \} \\ Criminal Law Department, Faculty of Law, Universitas Andalas, Padang, Indonesia
}

\begin{abstract}
The eradication of corruption in the private sector on the rule of law depends on two dimensions. The first element is repression, which emphasizes the imposition of criminal sanctions and the second is the preventive effort by fostering anti-corruption values in the organization. The general behavior of a person towards the rule of law is influenced by consideration of the incentives they may gain when they are law-abiding and the sanctions they may receive if they commit a crime or do not do what is required of them. This behavior also applies to corporations in making decisions relating to their obligation not to commit corruption. This paper analyses legal materials regarding the conditions under which corporate anti-corruption culture can provide legal implications in the commission of corruption within the corporation. This deploys normative juridical method that is in finding the data hold on juridical aspect by analyzing the legal materials with micro-comparative study and legislation approaches. This research is expected to provide input to corporations that by forming a corporate anti-corruption culture will bring legal implications that they may be able to obtain general defenses in criminal process of the corruption case if they have applied prudential principles in preventing corruption within the corporate environment reflected in the ethos, culture, and practices of the corporation.
\end{abstract}

Keywords: corporate criminal liability, corporate culture, anti-corruption culture, general corporate defense.

\section{Introduction}

Corruption is undoubtedly a behavior that endangers society at large. According to a report by Ernst and Young [1], corruption causes unhealthy competition between business actors, reducing public confidence in government institutions and slowing economic development. Dimant and Eugen also argue that corruption can lead to political instability, ineffective administrative services, and poor governance structures [2]. According to a report by Transparency International (TI) agency in 2016, although Indonesia's corruption perception index has improved but still very high. Currently, Indonesia is number 90 from 176 countries with an index of 37 out of a maximum of 100 . With widespread corruption behavior on all facet and lines, corruption eradication must also be conducted in all aspects. In addition to curative anti-corruption efforts, preventive effort to eradicate corruption is also very important to conduct.

One of the potential perpetrators of corruption is a corporation. The corporation is part of social and economic actors that has a significant role in the life of wide community. According to legal theory, corporations have different legal personality with its members [3]. 
They are independent legal subjects that can be the bearer of legal rights and/or obligations [4]. They may engage in legal relation, own property on its name, and as a consequence, they also may bear legal rights and duties for their deeds.

In carrying out, its activities corporation may engage in various conducts that may be classified as a crime. One form of criminal conduct that can be committed by a corporation is corruption. In contrast to individual corruption activities that is aim to gain personal interest, the corruption of a corporation is carried out in a coordinated manner by some corporate members for the benefit of the corporation itself [5]. As Finney and Lesieur (1982) explain that one of the main criteria to differentiate between individual and corporation's corruption is to determine actor who benefits from the conduct [6]. If the criminal act of corruption committed in favor of the corporation and or the owner or shareholder of the corporation, then the offense can be referred to as a criminal act committed by the corporation [7].

The fact that corporations could engage in corruption can be seen in some legal cases, for example, in the case of Siemens in 2008 in the United States, where Siemens was found guilty of corruption in many countries, using a special bank account to reduce the likelihood of being caught doing corruption [8]. Other major corruption case is Halliburton and Kellogg Brown \& Root (KBR) in the United States in 2009, BAE System 2010 in the UK, Alcatel - Lucent SA in 2010, JGC Corporation in the United States in 2011, Rolls Roys in the UK in 2016, which also involves public officials in Indonesia, and others. In Indonesia, for example, is corruption case of PT. Giri Jaladhi Wana in 2011 in Banjarmasin. In addition, currently, the Corruption Eradication Commission (KPK) suspected PT Duta Graha Indah involved in corruption in the construction of Special Education Hospital for Infectious Diseases and Tourism Udayana University in the 2009-2010 Budget Year [9].

An important curative effort to eradicate corruption is to ensure that every actor of corruption should be held accountable for his actions, including the corporation as a legal subject. Criminal sanctions aim to ensure that the offender can rehabilitate themselves and others are also afraid to do the same act [10]. In this case, the purpose of punishment for corporations is that corporations who commit crimes can improve themselves and other corporations will be more careful in deciding to engage in a criminal act of corruption. Individual criminal liability is perceived as having an insufficient effect on corporate behavior because the existence and behavior of a corporation do not depend on one or two people in the corporation. In addition, by penalizing the corporation, the possibility of returning state assets will be greater than simply punishing one or two individuals within the corporation alone [11].

In addition to curative anti-corruption efforts, preventive efforts are also necessary. One form of prevention of corruption behavior by corporations is to establish a law-abiding and anti-corruption corporate culture. According to Judge et al. corruption is not only a matter of economics and law but is also a moral issue [12]. Morality affects and is influenced by sociocultural norms of society. So that every organization, whether political, legal or economic organizations are obliged to behave by ethical norms. It is imperative for any corporation to adopt a comprehensive compliance program to prevent its employees from committing a criminal act of corruption, in most cases paying bribes to public officials for the benefit of corporations [8].

Corporate culture is the values and views shared by the employees of a corporation, in which these values and views influence corporate decision-making whether the individual employee makes the decision or group of individual makes the decisions for the benefit of the corporation. Liu uses the term of corporate corruption culture to explain the conditions under which a corporation has a behavior that generally leads to opportunistic behavior [13]. Still 
according to Liu, the higher the level of corporate corruption culture, the higher the likelihood of the corporation performing a non-lawful act [13].

Based on the background mention above, this paper tries to analyze and find solutions to these research questions: a) what is the role of corporate culture to the corporation's corrupt behavior and b) are there legal implications in a criminal case when the corporation has implemented an anti-corruption culture? This research is important because a corporation can also own corrupt behavior. There has not been much discussion by legal experts to see how corporations also have an important role in spreading the extent of corruption in society. Moreover, the anti-corruption policy is still very focused on bureaucracy without involving the role of corporations who are also important actors in corrupt activities. This research is expected to provide input for corporations to be able to have an awareness of the importance of forming an anti-corruption work culture by not tolerating various forms of corruption within the corporation.

In order to answer these research questions, this study deploys normative or doctrinal legal method, with micro-comparative and legislation approach.

This paper will be divided into five sections. The first section will discuss the importance of corporations as the subject of the criminal law of corruption and the role of corporations in shaping anti-corruption culture. This chapter also explains the subject matter, objectives and expected benefits of this paper, and the methodology used in conducting the research - the second part analyses the corporate criminal responsibility doctrine. The next section will discuss the corporate culture that leads to corruption, and it will continue with comparisons of legislation and the application of corporate criminal liability in criminal acts of corruption in several countries. The fourth section will contain an examination about corporate compliance program as a criminal defense. The last section is conclusions and suggestions.

\section{Corporate Criminal Liability Doctrine}

When explored in depth about corporate criminal liability doctrine, generally can be divided into five doctrines: vicarious liability, identification, aggregation, corporate culture and combined doctrine [14]. Vervaele divides these doctrines into two approaches, first is an indirect liability, where organizations are always considered acting through its members. Therefore, it must be seeking individuals who are in specific position within the corporation, whether it is the directors, other executives or other members, and then their actus reus and mens rea attributed to the corporation. Secondly is a direct liability, where actus reus and mens rea can be traced directly from the corporation. Direct liability approach is the development of realistic corporate personality theory [15]. Scholars who support realistic corporate personality, such as Lederman argues that corporations are self-identity that possessed all natural characteristics like a human [16]. If Vervaele's opinion associated with corporate criminal doctrine mentioned above, vicarious liability and identification doctrine are an indirect liability, while aggregation and corporate culture doctrines are a direct liability.

Vicarious criminal liability is a doctrine taken from the law of torts in civil law based on respondeat superior doctrine [17]. According to respondeat superior doctrine, a principal may be liable for its agent misconduct, if it is committed within their scope of employment [18].

The second doctrine is identification. Identification doctrine is the development of vicarious liability doctrine in corporate criminal liability [19]. This doctrine limits the doctrine of vicarious criminal liability that states that not everyone in the organization has sufficient 
status to cause corporations to be vicariously responsible for their crimes [20]. According to identification doctrine, corporations are identified through its key person or head of the corporations; these key persons are seen as legal alter ego of the corporations, so their actions are the actions of the corporation.

Next is the aggregation doctrine. According to aggregation doctrine, a corporation can own intention or group intention, which can be traced from the aggregation of will and actions of some key persons within the corporation [11]. Pursuant to Remmelink as cited by Muladi and Priyatno, shared knowledge of the boards of directors can be considered as corporation's knowledge [3]. Suprapto as also cited by Muladi and Priyatno asserts that corporation's culpability is collective culpability of the corporation's management [3]. Aggregation doctrine makes it easier to attribute criminal liability to the corporation because it eliminates the difficulty of identifying managerial culpability in large corporation [21].

The next doctrine is corporate culture or corporate disorganization doctrine. Pursuant to corporate culture doctrine, a corporation may own guilt by itself if the corporation's culture or working ethos enables the commission of the crime [11]. Corporate's cultures are transmitted from one generation to next generation unaffected by the change of personnel or members of the corporation [22]. It can be observed formally from corporate's procedures and policies, or informally on how those cultures influence the action and behavior of an individual's within the corporation [23].

The last is a combined doctrine proposed by Sjahdeini as an alternative to corporate criminal liability [18]. He explains ten elements to be fulfilled: the act is an offense, either an omission or commission; actus reus can be done or ordered by the directing mind or controlling mind of the corporation; mens rea is drawn from the directing mind's mens rea; benefit the corporation, crime is committed by utilizing corporate's existence, facility, or budget; the act is intra vires (within powers), carried out in the framework of the goal and purpose of the corporation; criminal act committed by directing the mind of the corporation is within his working scope and authority; if the actus reus is not carried out directly by the directing mind, the act shall be by order, or authorized, or approved by the directing mind, or consent shall be deemed to be granted if the directing mind does not prevent or prohibit the commission of the crime or fails to take adequate action when the offense occurred; there is no justification and excuse for the crime, actus reus, and mens rea do not have to be on one person but can be in some individuals within the corporation.

\section{Corporate Cultures That Lead to Criminal Conduct}

In general, experts view that there are two factors that cause corporations to commit corruption, especially in this case is paying a bribe. First, the view that states that corporations are rational profit maximizers. Corporations decide to pay bribes because the profit from the business is greater than the risk of being caught paying bribes or expected sanctions if the corporation gets caught [8]. The second view states that the corporation has made reasonable effort to fight corruption through the adoption of a compliance and ethics program, but one or several people from corporate employees still find ways to evade the system and pay bribes [24].

Corporate culture is a "web of attitudes and practices that tend to replicate and perpetuate itself."'[17]. Procedures and codes of ethics may also help define culture, as may supervision and discipline of employees. According to Harding, criminal liability may be imposed on a 
corporation if it has delinquent rationality, which may be attributable to corporate culture and processes of decision-making [25]. This corporate culture is either actively or passively permitting or tolerating non-compliance with legal provisions that lead to a crime [26]. So that criminal acts or violations committed cannot be seen as incidental or unexpected behavior from employees or members of the organization [16].

For example in the case of Enron, a culture of dishonesty, coupled with the wrong system of providing incentives, is exacerbated by the absence of good supervision, will allow group members to deceive shareholders and the wider community [27]. Alternatively, cases of injuries in the workplace are more often associated with overall management decisions about safety procedures and 'corporate culture,' which devalues employee safety standards, and are usually not caused by the carelessness of one company controller [28] - circumstances where the company may state that they care about the health and safety of their employees. However, the pressure given to individual employees is very high and unrealistic to be able to meet profit targets and time efficiency, so there is a possibility the company compromises the health and safety of its employees [26].

According to Yeager, corporate culture can be influenced by several factors including the personality of the company's leadership, the characteristics of the market where the company competes, and the vigilance and prudence of law enforcement officials [29].

Lederman asserts that in determining corporate criminal liability included in this category are also some of the following conditions: 1) a criminal act committed by a member of the corporation when a corporate procedure or policy may lead to the conduct of the act, 2) when the person who commits the crime is someone who is in an important position in corporate management, or when they instruct, encourage, or support the violation of the law, 3) when the corporation ratifies or gives explicit support for a violation committed by a member of the corporation (after committing a crime) [16].

De Maggie's opinion in explaining corporate criminal liability based on four examinations: 1) corporate policy, 2) corporate culture, 3) preventive faults, 4) reactive corporate faults [19]. Corporate policy in de Maglie's models are similar to the first opinion of Lederman, the corporate culture model is elaborating on the second opinion from Lederman, and the third opinion is what is called De Maglie reactive corporate fault. Preventive faults according to de Maglie, are when corporations fail to implement an internal system that is adequate to prevent criminal acts.

The corporate cultural doctrine is accepted in Australia and Switzerland in its Criminal Code. Section 12.3 of the Criminal Code Act of Australia explains that the element of error in the form of will, knowledge or negligence is attributed to the organization if explicitly, implicitly, secretly, authorizes or permits the occurrence of a criminal act.

Article 102 (1) Criminal Code Swiss states that an organization is responsible for a criminal act committed within the objective scope of the organization and in the implementation of organizational activities that cannot be blamed on certain individuals but occur due to constipation from the organization (disorganization).

Corporate criminal liability based on corporate culture is also accepted in the United Kingdom. From April 2008, the corporate culture may be an element of the offense of corporate manslaughter, where the way in which organizations' activities are managed and organized causes of death, and constitutes a gross breach of a relevant duty of care; and the way in which the organization's activities are managed or organized by its 'senior management' is a substantial element of the gross breach of the relevant duty of care [30]. Furthermore, this law also makes it possible to use corporate cultural doctrine in assessing whether a corporation can be held responsible for a crime. Section 8 (3) of this Act allows the 
jury to consider whether there is an attitude, policy, system, or practice that has been accepted by an organization that might encourage or tolerate criminal acts.

It can be concluded that culture, work ethic, policies, work systems, or practices that have generally been accepted by the organization, lead or tolerate crime [31].

\section{Corporate Compliance Program as a Defence}

Not all perpetrators of criminal acts can be held responsible. Criminal law does not only require harmful conduct to blame but also requires the existence of malicious intentions. There are several reasons for the remission of mistakes - for example the doctrine of insanity, infancy, defense of force that goes beyond the limits as stipulated in Article 49 (2) of the Indonesian Criminal Code, and an invalid job order as regulated in Article 51 (2) of the Criminal Code and intoxication. Also, there are also other defenses that are outside the regulation. For example afwezigheid van alle schuld (avas) or there is no mistake at all [32].

According to Diening, avast can be paralleled with the defense of due diligence at common law, because both aim to show that there is no guilt in the subject [33]. For a corporation, the defense of no fault or due diligence defense is one of the reasons that judges often consider for not imposing criminal liability [34].

For example, The United Kingdom Bribery Act of 2010 provides rules that reward compliance programs made by corporations. The Act provides that a corporation be strictly liable for a bribe committed by an employee, but it can use the defense of having adopted "adequate procedures" to prevent the bribe payment [35].

According to UK Ministry of Justice in its Bribery Act Guidance, the adequateprocedures defense is included in the Bribery Act "to encourage commercial organizations to put procedures in place to prevent bribery by persons associated with them [36]. The guidance details six anti-bribery procedures: proportionality, top-level commitment, risk assessment, due diligence, communication and training, and monitoring and review.

In the United States, the implementation of the U.S. Sentencing Guidelines also promotes compliance program, which emphasizes rewarding a company for efforts to "promote an organizational culture that encourages ethical conduct and a commitment to compliance with the law."'[17] U.S Sentencing Guidelines also provides that an organization with pre-existing compliance policies and procedures will likely to face lower fine amount when resolving corporate bribery than an organization without pre-existing policies and procedures [37]. In addition, based on the US Department of Justice Charging Policy, corporations that already have compliance programs can avoid being indicted and instead receive a settlement agreement [38].

The focus of the corporate culture reform is not trying to change everything about a company's culture, just its compliance with criminal law [17]. Real changes in corporate culture require sustained oversight of management, strong regulators, and sound rules and laws [17].

\section{Conclusion}

The Corporation should adopt a comprehensive compliance program to prevent its employees from paying bribes. The corporation must not think that anti-bribery culture is just 
as a legal compliance issue, but also as part of their social responsibility to society. From the government side must also provide incentives to corporations that have adopted and continually improve their compliance programs. However, it must be ensured that those who get rewards are corporations that implement effective compliance programs, not faulty compliance programs. That is a program that looks like it creates an attempt to prevent employees from paying bribes, but the company is not enforcing the program. The defense must be structured in a way that would encourage the corporation to implement a compliance program that is supported by ethical corporate culture. It is also important to make sure the defense can cause the corporation to improve their program regularly actively.

\section{References}

[1] Ernst and Young, 2008, Corruption or compliance - Weighing the costs, $10^{\text {th }}$ global fraud survey, available at http://www.ey.com/Publication/vwLUAssets/global_fraud_survey_2008/\$F ILE/EY_10TH_GLOBAL_FRAUD_SURVEY_2008.pdf

[2] Dimant and Eugen. The nature of corruption: An interdisciplinary perspective, Economics Discussion Papers, No. 2013-59. 2013.

[3] Muladi and Priyatno, Dwidja. Pertanggungjawaban pidana korporasi. 3rd edition, 5th printing. (Jakarta: Prenadamedia Group, 2015)

[4] Andrew Borkowski, Text book on roman law, reprinted 2cd Ed, (London: Blackstone Press Limited, 2001), p. 84.

[5] Brandy L. Aven, "The paradox of corrupt networks: an analysis of organizational crime at enron," Organization Science, vol. 26, No. 4, 2015, 980-996.

[6] Finney, H. C., \& Lesieur, H. R., A contingency theory of organizational crime. Research in the Sociology of Organizations, 1, 1982. 255-299.

[7] Pinto, Jonathan. Leana, Carri R. Pil, Frits K. Corrupt organizations or organizations of corrupt individuals? Two types of organization-level corruption, Academy of Management Review 2008, Vol. 33, No. 3, 685- 709.

[8] Hess, David. "Combating corruption in international business: The big questions." Ross School of Business Working Paper. No. 1285, Agustus 2015.

[9] Gabrillin, Abba. PT. Duta Graha Indah korporasi pertama yang dijadikan tersangka KPK, Kompas.com, 14/07/2017, accessed at 20 Oktober 2017.

[10] Singer, Richard G. and Fond, John Q. La. Criminal Law, $4^{\text {th }}$ edition, Austin: Wolters Kluwer, 2007.

[11] Pieth , Mark and Radha Ivory, "Emergence and convergence: corporate criminal liability principles in overview," in Mark Pieth and Radha Ivory (editor). Corporate criminal liability: emergence, convergence and risk, Mark Pieth and Radha Ivory (editor). (London: Springer, 2011), p. 5.

[12] Judge, W. Q. McNatt, D. B., \& Xu, W., 2011, The antecedents and effects on national corruption: A meta-analysis. Journal of World Business, 01, vol. 46, pp 93103.

[13] Liu, Xiaoding. "Corruption culture and corporate misconduct.” Journal of Financial Economics, vol. 112, Issue 2, 2016, 307-327.

[14] Pieth, Mark and Ivory, Radha. "Emergence and convergence: Corporate criminal liability principles in overview." In Mark Pieth and Radha Ivory (editor). Corporate 
criminal liability: Emergence, convergence and risk, Mark Pieth and Radha Ivory (editor). (London: Springer, 2011).

[15] Vervaele, John A. E., "Societas/universitas can be guilt and punished: 60 years of experience in the Netherlands," Derecho comparado y Derecho comunitario, Estudios de Derecho Judicial, 115, Madrid, 2007, 11- 64.

[16] Lederman, Eli. "Models for imposing corporate criminal liability: From adaptation and imitation toward aggregation and the search for self-identity." Buffallo Criminal Law Review. Vol. 4. No. 1. April 2000. 641-708.

[17] Garrett, Brandon L. Too big too jail: how prosecutors compromise with corporations. (London, England: The Belknap Press of Harvard University Press. 2014.

[18] Sjahdeini, Sutan Remy, Pertanggungjawaban pidana korporasi. $2^{\text {nd }}$ printing. (Jakarta: Grafiti Pers, 2007).

[19] Maglie, Chistina de. "Models of corporate criminal liablity in comparative law." Washington University Global Studies Law Review. Vol. 4. Issue 3. 2005. 547-566.

[20] Gobert, James. "Squaring the circle: the relationship between individual and organizational fault," in James Gobert and Ana-Maria Pascal (editor), European developments in corporate criminal liability (Oxon: Routledge, 2011).

[21] Cavanagh, Neil. "Corporate criminal liability: An assessment of the models of fault." The Journal of Criminal Law. 75. 2011. 414-440.

[22] Fisse and Braithwaite. Corporation, crime and accountability (Cambridge, UK: Cambridge University Press, 1993).

[23] Sarre, Rick. "White-collar crime and prosecution," in Hendry N. Pontell and Gilbert Geis (editor), International handbook of white-collar and corporate crime (New York, USA: Springer, 2007).

[24] Ashforth, Blake E. \& Anand, Vikas. The normalization of corruption in organizations. 25 Research on Organizational Behavior, 1, 23 (2003).

[25] Harding, Christopher. Criminal enterprise: individuals, organisations and criminal responsibility, (Willian Publishing. 2007).

[26] Sarre, Rick. "Penalising corporate 'culture': The key to safer corporate activity?" in James Gobert and Ana-Maria Pascal (editor), European developments in corporate criminal liability (Oxon: Routledge, 2011).

[27] Shockley, Kenneth. "Programming collective control." Journal of Social Philosophy, 38, 2007, 442.

[28] Foster, Neil. "Individual liability of company officers." In James Gobert and AnaMaria Pascal (editor). European developments in corporate criminal liability. (Oxon: Routledge, 2011).

[29] Yeager, Peter Cleary "Understanding corporate lawbreaking: from profit seeking to law finding," in Hendry N. Pontell and Gilbert Geis (editor), International handbook of white-collar and corporate crime. (New York, USA: Springer, 2007).

[30] United Kingdom, Corporate Manslaughter and Corporate Homicide Act 2007.

[31] Smiley, Marion. "From moral agency to collective wrongs: re-thinking collective moral responsibility.” Journal Of Law and Policy, 19, 171, 2010- 2011.

[32] Hiariej, Eddy O.S. Prinsip-Prinsip Hukum Pidana. (Yogyakarta: Cahaya Atma Pustaka, 2014).

[33] Diening, J.A.A, On reasonable liability: A comparison of Dutch and Canadian law regarding the limits of criminal liability. (Arnhem: Gouda Quint, 1982). 
[34] Wells, Celia. "Corporate criminal liability in England and Wales: past, present and present." In Corporate criminal liability: emergence, convergence and risk. Mark Pieth and Radha Ivory (editor). (London: Springer, 2011).

[35] United Kingdom. Bribery Act. 2010.

[36] United Kingdom, Ministry Of Justice, The Bribery Act 2010: Guidance 15 (2011), Available At Http://Www.Justice.Gov.Uk/Downloads/Legislation/Bribery-Act-2010Guidance.Pdf.

[37] Koehler, Mike. "Revisiting a foreign corrupt practices act compliance defense," Wisconsin Law Review, 2012:609.

[38] U S Department Of Justice, Criminal Division, A resource guide to the Foreign $\begin{array}{lllll}\text { Corrupt Practices Act } 56 \quad \text { (2012), Available At } & \text { Act }\end{array}$ Http://Www.Justice.Gov/Sites/Default/Files/CriminalFraud/Legacy/2015/01/16/Guide.Pdf. 